\title{
Switching Roles of TGF- $\beta$ in Cancer Development: Implications for Therapeutic Target and Biomarker Studies
}

\author{
Nan Sun ${ }^{1}$, Ayumu Taguchi ${ }^{2}$ and Samir Hanash ${ }^{1, *}$ \\ 1 Department of Clinical Cancer Prevention, the University of Texas MD Anderson Cancer Center, \\ Houston, TX 77030, USA; nsun@mdanderson.org \\ 2 Department of Translational Molecular Pathology, the University of Texas MD Anderson Cancer Center, \\ Houston, TX 77030, USA; ataguchi@mdanderson.org \\ * Correspondence: shanash@mdanderson.org; Tel.: +1-713-745-5242
}

Academic Editor: Andrei Turtoi

Received: 1 October 2016; Accepted: 22 November 2016; Published: 30 November 2016

\begin{abstract}
TGF- $\beta$ induces complicated and even opposite responses in numerous biological processes, e.g., tumor suppression in pre-malignant cells and metastasis promotion in cancer cells. However, the cellular contextual determinants of these different TGF- $\beta$ roles remain elusive, and the driver genes triggering the determinants' changes have not been identified. Recently, however, several findings have provided new insights on the contextual determinants of Smads in TGF- $\beta$ 's biological processes. These novel switches and their effectors may serve as prognostic biomarkers and therapeutic targets of TGF- $\beta$-mediated cancer progression.
\end{abstract}

Keywords: TGF- $\beta$; targeted therapy; role switch; biomarker

\section{Introduction}

Transforming growth factor- $\beta$ (TGF- $\beta$ ) plays key roles in many biological functions, such as embryonic stem cell self-renewal and differentiation, homeostasis of differentiated cells, suppression of the immune system, and promotion of cancer development [1]. The TGF- $\beta$ signaling pathway has been well characterized. TGF- $\beta$ binds to its receptor on the cell membrane and induces a signaling cascade by phosphorylating Smad2/3. Phosphorylated Smad2/3 binds to Smad4, and the complex translocates from the cytoplasm to the nucleus to activate the transcription of end effectors such as p15, p21, and PTHrP [2,3]. In normal epithelial cells, TGF- $\beta$ induces the activation of cytostatic genes, including $p 15$ [4] and $p 21$ [5-7]. TGF- $\beta$ also inhibits a set of genes that promote cell growth, including $c-M Y C$ [8-10]. In addition to the canonical TGF- $\beta$ /Smad signaling pathway, TGF- $\beta$ can activate several non-canonical signaling pathways. For example, TGF- $\beta$ regulates Erk, p38, MAPK, JNK, PI3K-Akt, and small GTPases [11,12].

An emerging notion is that cellular contextual functionality, more than TGF- $\beta$ itself, dictates the complicated and even opposite natures of TGF- $\beta$-induced responses. In this review, we summarize recent findings about the role switching of TGF- $\beta$ in cancer development; these findings shed light on potential therapeutic targets in the TGF- $\beta$ signaling pathway and predictive biomarkers for anti-TGF- $\beta$ therapy.

\section{The Context-Dependent Functions of TGF- $\beta$ in Normal Tissues}

Although the signaling cascade of TGF- $\beta$ involves only a few Smad proteins and seems simpler than other receptor-mediated signaling pathways, the cellular responses to TGF- $\beta$ are complicated and are highly dependent upon the cellular context [1]. Most of this context dependency can be explained 
by the interactions between Smads and a wide-ranging complement of DNA sequence-binding transcription factors, including p53 and members of the bHLH, Forkhead box (Foxo), and Zinc finger protein families [13]. For example, in neuroepithelial and glioblastoma cells, TGF- $\beta$ induces Smad3/4 to form a complex with Foxo3a to activate $p 21$ gene expression [5]. However, several other reports showed that this complex does not exist in human mammary epithelial cells. Instead, an alternative mechanism for p21 activation in response to TGF- $\beta$, involving p53 and Smad $2 / 3 / 4$, has been identified in a mammary epithelial cell line MCF-10A [14-17]. Interestingly, TGF- $\beta$ reportedly induces $p 21$ through a p53-independent mechanism in the HaCaT cell line, which contains two mutant alleles of p53 that cannot activate transcription of $p 21$ [18]. Taken together, these data show that TGF- $\beta$ 's signaling program is highly dependent on cell context.

It has been known for decades that TGF- $\beta$ induces complicated and even opposite responses in many biological processes as a consequence of various contextual determinants for Smad. In particular, Smads activate a lineage-specific transcriptional program in cooperation with lineage-specific transcription factors during cell differentiation $[19,20]$. For example, TGF- $\beta$-activated or bone morphogenetic protein-activated Smads collaborate with MYOD1 in myoblasts or with PU.1 in pre-B cells [19]. Additionally, CCAAT-enhancer binding protein (C/EBP)- $\alpha$ recruits Smads in myeloid precursors, while GATA1 works with Smads in erythroid precursors to initiate differentiation into these two lineages [20]. In embryonic stem cells, the same Smad complexes bind to FOXH1, a mesendoderm lineage factor, to initiate the expression of multiple differentiation genes [21,22]. However, bone morphogenetic protein-activated Smad1 and the leukemia inhibitory factor mediator STAT3 form a self-renewal network with the pluripotency core complex OCT4-SOX2-NANOG in embryonic stem cells $[23,24]$. Moreover, TGF- $\beta$ plays a role in regulating the expression of normal tissue homeostasis genes such as SERPINE1, CDKN1A, MYC, and ID1 in differentiated cells with various Smad co-transcription factors, including AP1, FOXO1, E2F4, and ATF3, respectively [5,25-29].

\section{The Context-Dependent Functions of TGF- $\beta$ in Cancer Development}

TGF- $\beta$ is primarily a tumor suppressor that inhibits proliferation or induces apoptosis of premalignant epithelial cells [29]. In the later stages of cancer progression, however, TGF- $\beta$ functions as a metastasis promoter by inducing epithelial-mesenchymal transition (EMT), leading to increased invasion of cancer cells, and by inducing genes that facilitate metastatic colonization of secondary organ sites (e.g., lung, bone, liver, and brain) [29]. Although the opposing functions of TGF- $\beta$ in earlyand late-stage cancer have been known for years, it is unclear how and when TGF- $\beta$ switches from tumor suppressor to metastasis promoter. An emerging notion is that cellular contextual functionality dictates the divergent roles of TGF- $\beta$. However, the cellular contextual determinants for Smads in response to TGF- $\beta$ in different cells and the driver genes that trigger the changes of contextual determinants for Smads have never been well understood.

Several studies have attempted to identify these determinants and drivers. For example, TMEPAI knockdown attenuates TGF- $\beta$-induced growth and motility in breast cancer cells [30]. miR-106b was identified as a molecular switch that determines TGF- $\beta$ 's effects on cell proliferation, is elevated in late-stage tumors, and correlates with tumor progression in breast cancer patients. TGF- $\beta$ increases the transcription of miR-106b by activating c-Jun to bind to its promoter. However, miR-106b upregulation counterbalances the growth-inhibiting effects by abolishing activated retinoblastoma protein, resulting in enhanced proliferation. Thus, as a downstream target of TGF- $\beta$, miR-106b could direct the tumor-promoting functions of TGF- $\beta$ in breast cancer [31]. In an established model of TGF- $\beta$-induced EMT in mouse mammary gland epithelial cells, C/EBP $\beta$ is repressed by miR-155, an oncomiR. Depletion of $C / E B P \beta$ enhances TGF- $\beta$-induced EMT by decreasing the transcription of E-cadherin and of the coxsackie virus and adenovirus receptor, contributes to evasion of the growth-inhibitory effect of TGF- $\beta$, and further enhances invasion and metastatic dissemination of the mouse mammary tumor cells to the lungs after subcutaneous injection into mice [32]. The role switching of TGF- $\beta$ from tumor promoter to tumor suppressor is also shown in the reprogramming 
of MDA-MB-231 triple-negative breast cancer cells with the GATA3 transcription factor. GATA3 overexpression in these cells reduces TGF- $\beta$ response, reverses EMT, and restores sensitivity to TGF- $\beta$ 's inhibitory effects on cell proliferation in MDA-MB-231 cells. In addition, overexpression of GATA3 in MDA-MB-231 cells results in the reprogramming of these cells from a basal to a luminal subtype, which has been associated with reduced metastasis and reduced tumorigenesis in a xenograft model [12]. Latency-associated protein, an active isoform of transcription factor $C / E B P \beta$, is essential for TGF- $\beta$ induction of the cell cycle inhibitor p15INK4b together with a Foxo-Smad complex and repression of c-MYC with an E2F4/5-Smad complex in human mammary epithelial cells. However, the cytostatic response is selectively missing in metastatic cancer cells and patient samples owing to an excessive expression of LIP, which is the natural dominant negative inhibitory isoform of $C / E B P \beta$. These data suggest that $C / E B P \beta$, especially the ratio of LIP to latency-associated protein, plays a key role in the coordination of TGF- $\beta$ cytostatic responses, and its malfunction may trigger evasion of these responses in cancer [25].

It has been suggested that mutated $p 53$ switches TGF- $\beta$ from a tumor suppressor to a metastasis promoter. $p 53$ is the most frequently mutated gene as cancer evolves [33] and has been identified as a Smad binding partner for TGF- $\beta$-induced $p 21$ gene expression and cytostatic function $[14,16,17,34,35]$. Wild-type p53 inhibits TGF $\beta$-induced EMT and EMT-associated stemness in a mammary epithelial cell model [36,37]. A possible mechanism of this inhibition is that p53 regulates the expression of EMT mediator-Zeb1/2 and stem cell executor-BMI1 through transcriptional activation of miR-200c [37], which is also a downstream target of the TGF- $\beta$ signaling pathway [38-40]. Meanwhile, expression of mutant p53 (R273H) or loss of p53 inhibits the suppressive function of TGF- $\beta$ in cell proliferation in an ovarian cancer cell line [41]. An important study which was conducted in lung cancer cell line H1299 and ovarian cancer cell line SKOV3 showed that cells expressing mutant p53 lost their sensitivity to TGF- $\beta$. This is because the mutant $p 53$ attenuates TGF- $\beta$ signaling and TGF- $\beta$-induced transcription activity of Smad $2 / 3$ proteins by reducing the expression of TGF- $\beta$ type II receptor [42]. These studies provide insight into the molecular mechanisms of mutant p53 "gain of function" pertaining to the TGF- $\beta$ signaling pathway.

TGF- $\beta$ plays a range of roles in various types of cancer. In prostate tumorigenesis, PPAR $\delta$ is a direct transcription target of TGF- $\beta$ and plays a critical role in switching the function of TGF- $\beta$. PPAR $\delta$ induction inhibited TGF- $\beta$-mediated growth inhibition, while its activation promoted TGF- $\beta$-induced tumor growth, migration, and invasion. Mechanistically, TGF- $\beta$ activation of the PPAR $\delta$-ABCA1-Cav1 pathway facilitates degradation of TGF- $\beta$ receptors and attenuates Smad activity and growth inhibitory function but enhances the ERK signaling pathway in response to TGF- $\beta$ [43].

Changes in the cellular microenvironment including tissue stiffness and matrix rigidity could also affect the functional response to TGF- $\beta$. Low rigidity increases TGF- $\beta$-induced apoptosis, but high rigidity results in EMT. Matrix rigidity does not change Smad signaling; instead it regulates the PI3K/Akt signaling pathway, which also plays a critical role in the apoptotic and EMT responses. These findings provide insight into how tissue mechanics might contribute to the cellular response to TGF- $\beta$ [44].

The above studies have partially revealed TGF- $\beta$ 's functions and role switch in cancer development. However, not all of these studies exactly explain how TGF- $\beta$ loses its tumor suppressor function during cancer initiation, as most of the data were obtained from cancer cell lines in which TGF- $\beta$ had already gained a tumor promoter function. Moreover, most of the TGF- $\beta$ studies were focused on cell proliferation and tumor growth, which are only part of TGF- $\beta$ 's functions. More effort is needed to comprehensively understand the mechanism of the role switch of TGF- $\beta$. 


\section{Challenges in Current Cancer Therapy Targeting TGF- $\beta$ and Implications for Biomarker Studies}

Since the TGF- $\beta$ signaling pathway plays an important role in cancer development and a variety of other diseases, much effort has gone toward developing cancer therapeutics to target TGF- $\beta$ signaling in both the tumor and its microenvironment [45-49]. Currently, several TGF- $\beta$ signaling antagonists, including antisense molecules, ligand traps for inhibition of the ligand-receptor interaction, anti-receptor monoclonal antibodies, TGF- $\beta$ receptor kinases inhibitors, and aptamers, have been developed and applied to clinical practice [50].

The critical function of the TGF- $\beta$ pathway in cancer, especially in the context of metastasis, spurred the development of TGF- $\beta$ antagonists, yet these showed limited clinical efficacy [51,52]. In limited phase I and II trials for treating cancers generally overexpressing TGF- $\beta$, some patients with advanced cancers received a marginal benefit from TGF- $\beta$ inhibitors $[53,54]$. However, more antagonists were developed and passed the pre-clinical trials, and they are now tested in ongoing Phase I/II clinical trials [55]. Considering the opposing roles of TGF- $\beta$ in cancer, it is not surprising that its general inhibition may have unexpected deleterious consequences. Inhibiting TGF- $\beta$ may accelerate the development of pre-neoplastic lesions in which TGF- $\beta$ still acts as a tumor suppressor. For example, conditional knockout of TGFBR2 in the mammary gland before tumors were established resulted in shorter median tumor latency and more pulmonary metastases [56]. Moreover, attenuated TGF- $\beta$ signaling along with high VEGFA expression was correlated with shorter distant metastasis-free survival in HER2+ breast cancer patients [57]. In contrast, a short induction of TGF- $\beta$ expression after tumors were established clearly accelerated metastatic progression [58].

As tumors evolve, TGF- $\beta$ switches its role from tumor suppressor to tumor promoter. The complex nature and dual roles of TGF- $\beta$ in cancer have impeded the development of effective therapies that target only the tumor-promoting activities of TGF- $\beta$. Thus, screening the individual genetic background as well as the tumor microenvironment will be highly beneficial for predicting patients' responses to a TGF- $\beta$ antagonist. The key players of the TGF- $\beta$ signaling pathway are previous biomarkers such as TGF $\beta$ R2, Smad2, and Smad4 by tumor biopsy or genetic analysis [59-63]. However, several reports showed that loss of TGF $\beta R 2$ expression is associated with more aggressive tumor behavior and reduced survival in human lung adenocarcinoma and squamous cell carcinoma [64]. These contradicting reports suggest that these key players of the TGF- $\beta$ signaling pathway are not always reliable for predicting response to TGF- $\beta$ inhibitory therapy and may have totally opposite, misleading impacts. Significant advances have been made in understanding the molecular mechanisms by which TGF- $\beta$ switches from tumor suppressor to promoter, and several proteins that are changed during the switch, such as Six1, Dab2, 14-3-3द, PEAK1, p53, and Gli2, could serve as new biomarkers (Figure 1). Meanwhile, it is essential to develop circulating biomarkers to identify patients who are sensitive to TGF- $\beta$-targeting therapy and to determine the timing of patients' responses to TGF- $\beta$ antagonists to improve therapeutic efficacy. There could be additional noninvasive, blood-based biomarkers for predicting individual patient response to TGF- $\beta$ inhibitors. Since TGF- $\beta$ inhibitors may modulate the immune system, circulating autoantibodies could be used to monitor response [52]. Any of the following biomarkers alone or in combination could be used in the future to predict tumor response to TGF- $\beta$ inhibition. 


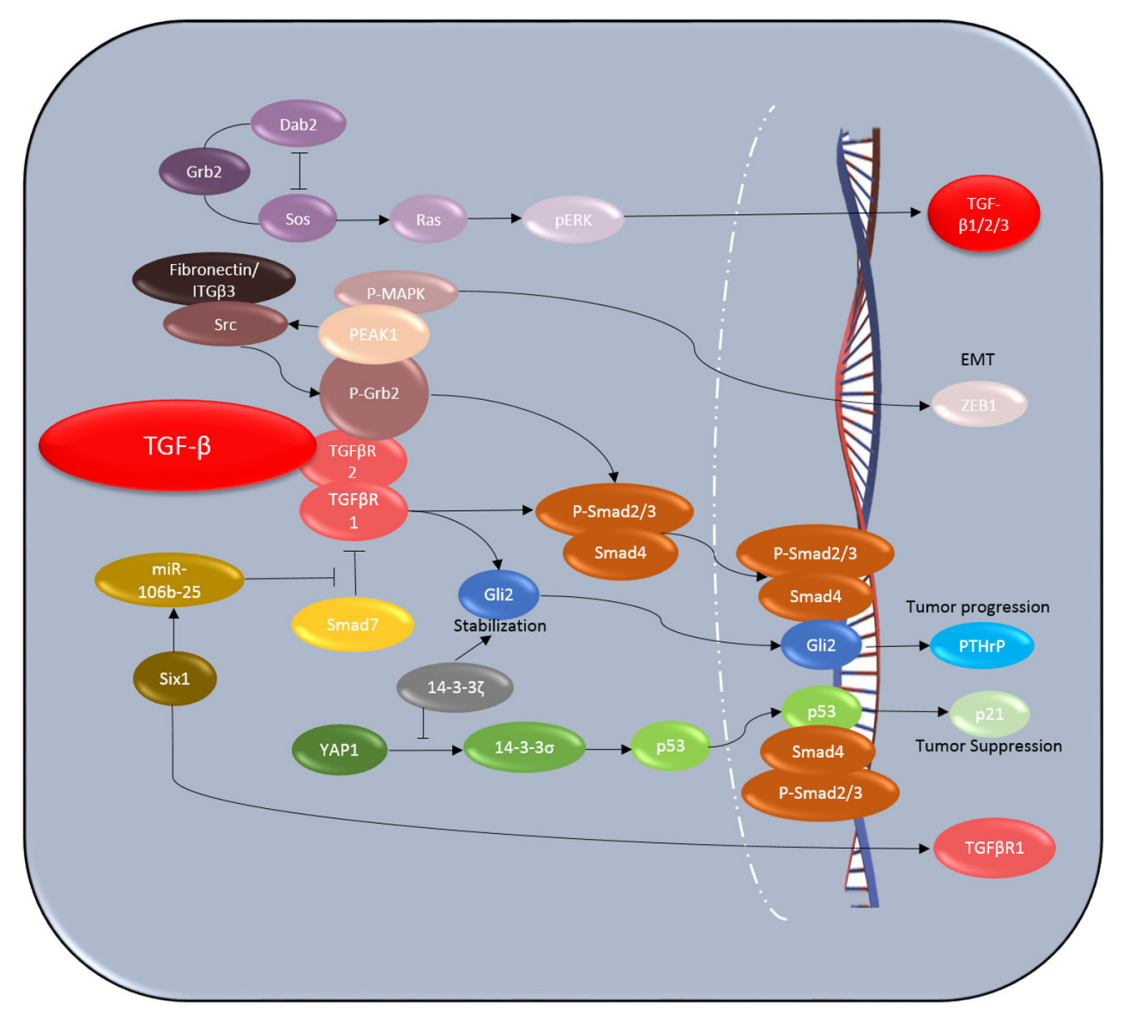

Figure 1. Schematic diagram of the context-dependent TGF- $\beta$ signaling pathway.

\subsection{Six1}

Six1 is a developmentally regulated homeoprotein that has frequent misexpression in various types of cancer but shows limited expression in most normal adult tissues. Overexpression of human Six1 in adult mouse mammary gland epithelium induces aggressive mammary tumor formation and EMT in a dose-dependent manner [65]. Six1 is correlated with nuclear Smad3 and increases TGF- $\beta$ signaling, promoting metastasis and relapse in breast cancer [66]. Furthermore, the same group showed more evidence that Six1-induced upregulation of TGF- $\beta$ type I receptor is required to switch TGF- $\beta$ signaling to the prometastatic phenotype [67]. They also identified another mechanism by which Six1 upregulates the miR-106b-25 microRNA cluster to target inhibitory Smad7, resulting in increased levels of TGF- $\beta$ type I receptor and activation of TGF- $\beta$ signaling later [11]. A similar function in which Six 1 coordinates with TGF- $\beta$ signaling and promotes EMT was also observed in cervical cancer [68]. Together these findings suggest that Six1 can switch the role of TGF- $\beta$ to tumor promoter, and it could serve as a therapeutic target and prognostic biomarker.

\section{2. $D a b 2$}

Disabled-2 (Dab2), a structural homologue of the Dab1 adaptor molecule, acts as a critical link between the TGF- $\beta$ receptors and Smads [69]. Previous studies showed that TGF- $\beta$-induced Dab2 expression levels block visceral endoderm differentiation, stimulate JNK activity, and promote cell migration [70,71]. Moreover, via transcript-selective translational induction of Dab2, TGF- $\beta$-mediated phosphorylation of hnRNP E1 can induce EMT [72]. However, recent studies have demonstrated that the downregulation of Dab2 expression via promoter methylation is an independent predictor of metastasis and poor prognosis in squamous carcinoma [73]. Downregulation of Dab2 abrogates the TGF- $\beta$ tumor suppressor function by blocking TGF- $\beta$-mediated inhibition of cell proliferation and migration and facilitates TGF- $\beta$-stimulated EMT [74]. A study in which Dab2 was re-expressed in SK-BR-3 cells found that TGF- $\beta$ was depleted in the surrounding medium via normalization of the trafficking of TGF- $\beta$ receptors [75]. Moreover, low expression of Dab2 occurred in esophageal 
squamous cell carcinoma, associated with poor survival and high recurrence [76]. Together, these data indicate that Dab2 is an important regulator of TGF- $\beta$ signaling, which could aid in the inhibition of cancer and the selection of patients for anti-TGF- $\beta$ therapies.

\section{3. $14-3-3 \zeta$}

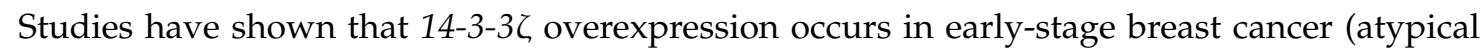

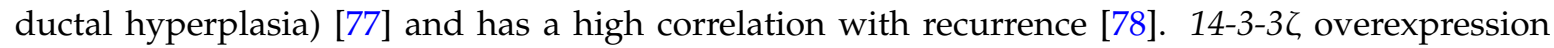
activated the TGF- $\beta$ /Smad pathway, which led to ZFHX1B/SIP-1 upregulation, E-cadherin loss, and EMT [79]. TGF- $\beta$ induces $p 21$ expression and cytostatic function in non-malignant HMECs through the p53/Smad complex. Surprisingly, a recent study found direct evidence that overexpression of 14-3-3乙 inhibits TGF- $\beta$ 's cell cytostatic program in non-transformed human mammary epithelial cells, while overexpression of $14-3-3 \zeta$ promotes TGF- $\beta$-induced metastatic colonization of bone by breast

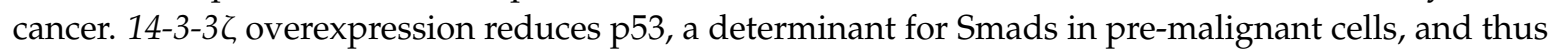

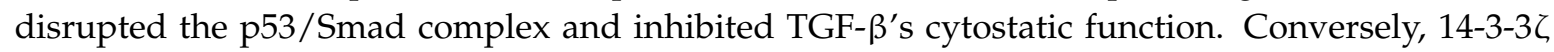
stabilizes Gli2, a determinant for Smads in late-stage cancer, forming a complex with Smads to promote TGF- $\beta$-induced bone metastasis of breast cancer. Together, these results identify $14-3-3 \zeta$ as a novel molecular switch of TGF- $\beta$ 's function by alteration of contextual determinants for Smads, from p53 in pre-malignant cells to Gli2 in late-stage cancers [80]. This finding suggests that $14-3-3 \zeta$ can switch TGF- $\beta$ from tumor suppressor to tumor promoter, indicating that it could be a novel biomarker to aid in the selection of the patients who and when will benefit from TGF- $\beta$ antagonists [29,51].

\subsection{PEAK1}

Pseudopodium-enriched atypical kinase 1 (PEAK1), Sgk269, is a 190 kDa non-receptor tyrosine kinase that controls cell spreading, migration, and proliferation [81,82]. Amplified PEAK1 levels were found in colon cancer, pancreatic cancer, and breast cancer, suggesting that it is a potential therapeutic target [82,83]. However, a study in gastric cancer showed $71.1 \%$ negative expression of PEAK1 in the cancer tissues and indicated that loss of PEAK1 may activate EMT and promote cancer development [84]. Recently, studies indicated that PEAK1 acts as a molecular switch that regulates context-dependent TGF- $\beta$ responses in breast cancer [85]. High expression levels of PEAK1 cause the loss of the anti-proliferative effects of TGF- $\beta$ and initiate TGF- $\beta$-induced proliferation, EMT, cell migration, and tumor metastasis with the presence of fibronectin by switching TGF- $\beta$ signaling from the canonical Smad2/3 pathway to Src and MAPK signaling. Moreover, PEAK1 is necessary for TGF- $\beta$-induced ZEB1-mediated EMT in the presence of fibronectin/ITGB3 activation [86]. Thus, PEAK1 can be used to determine when TGF- $\beta$ blockade is viable in targeted therapy of breast cancer.

\section{5. $p 53$}

Since p53 has been reported to be a critical Smad partner and to be responsible for TGF- $\beta$ 's cytostatic function, p53 can be used as a biomarker for selecting patients whose TGF- $\beta$ has lost its inhibitory effect on cell proliferation. In the late stages of cancer development, p53 is lost or mutated in approximately $50 \%$ of cases [87]. In addition, p53 mutation could contribute to TGF- $\beta$ 's function switch. As shown in a previous study, an R280K mutation was found in p53 in MDA-MB-231 cells, and this mutant p53 can still form a complex with Smads and enhance TGF- $\beta$-induced metastasis [15]. Furthermore, loss of p53 has been reported to induce EMT in HMECs [88], suggesting that p53 loss occurring downstream of 14-3-3乙 may be a switching point in the role of TGF- $\beta$, similar to p53 mutation [15]. Recently, a study in lung cancer showed that the radiosensitizing effect of inhibition of TGF- $\beta$ signaling by SB431542 in non-small cell lung cancer cells was p53-dependent, also suggesting that p53 should be considered during anti-TGF- $\beta$ treatment [89]. 


\subsection{Gli2}

Gli2 is overexpressed in a variety of cancers and has a direct function in cell cycle progression, apoptosis, invasion, and metastasis [90,91]. It has been reported that TGF- $\beta$ treatment induced Gli2 mRNA transcription in MDA-MB-231 cells [92]. Additionally, studies have shown that TGF- $\beta$ induced an immediate increase in Gli2 protein via 14-3-3ろ-mediated stabilization of Gli2 in MDA-MB-231 cells, suggesting that TGF- $\beta$ induces Gli2 expression at multiple levels, not simply by transcriptional upregulation. TGF- $\beta$ is known to induce parathyroid hormone-related protein $(P T H r P)$ expression via Gli2, independently of the canonical Hedgehog pathway, enhancing bone metastasis [93]. It was reported that TGF- $\beta$-activated Smads transcriptionally unregulated Gli2, which subsequently transcriptionally unregulated PTHrP [92]. Recently, it was found that TGF- $\beta$-activated Smads can directly bind to Gli2 protein stabilized by $14-3-3 \zeta$ and that the Smad/Gli2 complex transcriptionally upregulates PTHrP [80]. This indicates that TGF- $\beta$-activated Smads can induce PTHrP expression via Gli2 by at least two mechanisms: (a) indirectly, via Gli2-induced PTHrP transcription; and (b) directly, by forming a complex with Gli2 to turn on PTHrP transcription. These findings suggest that Gli2 could serve as a biomarker for monitoring the role switch of TGF- $\beta$.

\subsection{Circulating TGF- $\beta$ and TGF- $\beta$-Associated Markers}

The most direct biomarkers for patient selection for anti-TGF- $\beta$ antagonists are circulating TGF- $\beta$ in blood [94] and p-Smad2 levels in peripheral mononuclear cells [95]. Circulating TGF- $\beta$ was assessed in previous studies in the blood samples of breast cancer patients [96]. The level of TGF- $\beta$ in advanced-stage breast cancer was much higher than in early-stage breast cancer and has been associated with poor prognosis [97]. Another study, of an autoimmune disease, showed that the level of circulating TGF- $\beta$, which could help suppress immune functions, was elevated while the level of autoantibodies was decreased in blood [98]. Interestingly, our comprehensive proteomic profiling of pre-diagnostic plasma collected from patients who were diagnosed with lung cancer within two years revealed that circulating TGF- $\beta$ levels were associated with the timing of the blood draw and levels of a set of circulating proteins known to be immunogenic in lung cancer. Our data suggested that, with the increase of TGF- $\beta$ and the switch of its functions, the levels of tumor antigens increased, but the levels of autoantibodies against tumor antigens decreased (unpublished data). Those findings suggest that circulating TGF- $\beta$ levels are associated with not only tumor biology but also systemic host response to tumors, which precedes clinical diagnosis, and thus that TGF- $\beta$, antigens emanating from tumors, and autoantibodies against tumor antigens are potential biomarkers for early detection of cancer.

\section{Conclusions and Perspectives}

The strategy of targeting TGF- $\beta$ has been investigated in many different cancer types. However, TGF- $\beta$ has different functions during cancer initiation and development, which may cause a failure of therapy targeted to TGF- $\beta$ signaling. The switching roles of TGF- $\beta$ have been studied for decades, and much effort has gone into the development of this targeted therapy. Recently, a few important proteins have been identified as the key switches, most of which were verified only in particular types of cancer. There is an urgent need to develop novel therapeutic strategies to address TGF- $\beta$ signaling and to discover new biomarkers to optimize the timing of the therapy, which together could significantly impact cancer patient care in the new era of personalized cancer medicine [99].

Conflicts of Interest: The authors declare no conflict of interest.

\section{References}

1. Massague, J. TGF $\beta$ signalling in context. Nat. Rev. Mol. Cell Biol. 2012, 13, 616-630. [CrossRef] [PubMed]

2. Yin, J.J.; Selander, K.; Chirgwin, J.M.; Dallas, M.; Grubbs, B.G.; Wieser, R.; Massagué, J.; Mundy, G.R.; Guise, T.A. TGF- $\beta$ signaling blockade inhibits PTHrP secretion by breast cancer cells and bone metastases development. J. Clin. Investig. 1999, 103, 197-206. [CrossRef] [PubMed] 
3. Siegel, P.M.; Massague, J. Cytostatic and apoptotic actions of TGF- $\beta$ in homeostasis and cancer. Nat. Rev. Cancer 2003, 3, 807-821. [CrossRef] [PubMed]

4. Seoane, J.; Pouponnot, C.; Staller, P.; Schader, M.; Eilers, M.; Massague, J. TGF $\beta$ influences Myc, Miz-1 and Smad to control the CDK inhibitor p15INK4b. Nat. Cell Biol. 2001, 3, 400-408. [CrossRef] [PubMed]

5. Seoane, J.; Le, H.V.; Shen, L.; Anderson, S.A.; Massague, J. Integration of Smad and forkhead pathways in the control of neuroepithelial and glioblastoma cell proliferation. Cell 2004, 117, 211-223. [CrossRef]

6. Pardali, K.; Kurisaki, A.; Moren, A.; ten Dijke, P.; Kardassis, D.; Moustakas, A. Role of Smad proteins and transcription factor Sp1 in p21(Waf1/Cip1) regulation by transforming growth factor- $\beta$. J. Biol. Chem. 2000, 275, 29244-29256. [CrossRef] [PubMed]

7. Moustakas, A.; Kardassis, D. Regulation of the human p21/WAF1/Cip1 promoter in hepatic cells by functional interactions between Sp1 and Smad family members. Proc. Natl. Acad. Sci. USA 1998, 95, 6733-6738. [CrossRef] [PubMed]

8. Chen, C.R.; Kang, Y.; Siegel, P.M.; Massague, J. E2F4/5 and p107 as Smad cofactors linking the TGF $\beta$ receptor to c-myc repression. Cell 2002, 110, 19-32. [CrossRef]

9. Claassen, G.F.; Hann, S.R. A role for transcriptional repression of p21CIP1 by c-Myc in overcoming transforming growth factor $\beta$-induced cell-cycle arrest. Proc. Natl. Acad. Sci. USA 2000, 97, 9498-9503. [CrossRef] [PubMed]

10. Chen, C.R.; Kang, Y.; Massague, J. Defective repression of c-myc in breast cancer cells: A loss at the core of the transforming growth factor $\beta$ growth arrest program. Proc. Natl. Acad. Sci. USA 2001, 98, 992-999. [CrossRef] [PubMed]

11. Smith, A.L.; Iwanaga, R.; Drasin, D.J.; Micalizzi, D.S.; Vartuli, R.L.; Tan, A.C.; Ford, H.L. The miR-106b-25 cluster targets Smad7, activates TGF- $\beta$ signaling, and induces EMT and tumor initiating cell characteristics downstream of Six1 in human breast cancer. Oncogene 2012, 31, 5162-5171. [CrossRef] [PubMed]

12. Chu, I.M.; Lai, W.C.; Aprelikova, O.; El Touny, L.H.; Kouros-Mehr, H.; Green, J.E. Expression of GATA3 in MDA-MB-231 triple-negative breast cancer cells induces a growth inhibitory response to TGFss. PLoS ONE 2013, 8, e61125. [CrossRef] [PubMed]

13. Feng, X.H.; Derynck, R. Specificity and versatility in tgf- $\beta$ signaling through Smads. Annu. Rev. Cell Dev. Biol. 2005, 21, 659-693. [CrossRef] [PubMed]

14. Piccolo, S. p53 regulation orchestrates the TGF- $\beta$ response. Cell 2008, 133, 767-769. [CrossRef] [PubMed]

15. Adorno, M.; Cordenonsi, M.; Montagner, M.; Dupont, S.; Wong, C.; Hann, B.; Solari, A.; Bobisse, S.; Rondina, M.B.; Guzzardo, V.; et al. A Mutant-p53/Smad complex opposes p63 to empower TGF $\beta$-induced metastasis. Cell 2009, 137, 87-98. [CrossRef] [PubMed]

16. Cordenonsi, M.; Dupont, S.; Maretto, S.; Insinga, A.; Imbriano, C.; Piccolo, S. Links between tumor suppressors: 553 is required for TGF- $\beta$ gene responses by cooperating with Smads. Cell 2003, 113, 301-314. [CrossRef]

17. Cordenonsi, M.; Montagner, M.; Adorno, M.; Zacchigna, L.; Martello, G.; Mamidi, A.; Soligo, S.; Dupont, S.; Piccolo, S. Integration of TGF- $\beta$ and Ras/MAPK signaling through p53 phosphorylation. Science 2007, 315, 840-843. [CrossRef] [PubMed]

18. Datto, M.B.; Li, Y.; Panus, J.F.; Howe, D.J.; Xiong, Y.; Wang, X.F. Transforming growth factor $\beta$ induces the cyclin-dependent kinase inhibitor p21 through a p53-independent mechanism. Proc. Natl. Acad. Sci. USA 1995, 92, 5545-5549. [CrossRef] [PubMed]

19. Mullen, A.C.; Orlando, D.A.; Newman, J.J.; Loven, J.; Kumar, R.M.; Bilodeau, S.; Reddy, J.; Guenther, M.G.; DeKoter, R.P.; Young, R.A. Master transcription factors determine cell-type-specific responses to TGF- $\beta$ signaling. Cell 2011, 147, 565-576. [CrossRef] [PubMed]

20. Trompouki, E.; Bowman, T.V.; Lawton, L.N.; Fan, Z.P.; Wu, D.C.; DiBiase, A.; Martin, C.S.; Cech, J.N.; Sessa, A.K.; Leblanc, J.L.; et al. Lineage regulators direct BMP and Wnt pathways to cell-specific programs during differentiation and regeneration. Cell 2011, 147, 577-589. [CrossRef] [PubMed]

21. Chiu, W.T.; Charney Le, R.; Blitz, I.L.; Fish, M.B.; Li, Y.; Biesinger, J.; Xie, X.; Cho, K.W. Genome-wide view of TGF $\beta$ /Foxh1 regulation of the early mesendoderm program. Development 2014, 141, 4537-4547. [CrossRef] [PubMed]

22. Liu, F.; Pouponnot, C.; Massague, J. Dual role of the Smad4/DPC4 tumor suppressor in TGF $\beta$-inducible transcriptional complexes. Genes Dev. 1997, 11, 3157-3167. [CrossRef] [PubMed] 
23. Chen, X.; Xu, H.; Yuan, P.; Fang, F.; Huss, M.; Vega, V.B.; Wong, E.; Orlov, Y.L.; Zhang, W.; Jiang, J.; et al. Integration of external signaling pathways with the core transcriptional network in embryonic stem cells. Cell 2008, 133, 1106-1117. [CrossRef] [PubMed]

24. Ying, Q.L.; Nichols, J.; Chambers, I.; Smith, A. BMP induction of Id proteins suppresses differentiation and sustains embryonic stem cell self-renewal in collaboration with STAT3. Cell 2003, 115, 281-292. [CrossRef]

25. Gomis, R.R.; Alarcon, C.; Nadal, C.; Van Poznak, C.; Massague, J. C/EBP $\beta$ at the core of the TGF $\beta$ cytostatic response and its evasion in metastatic breast cancer cells. Cancer Cell 2006, 10, 203-214. [CrossRef] [PubMed]

26. Schier, A.F. Nodal morphogens. Cold Spring Harb. Perspect. Biol. 2009, 1, a003459. [CrossRef] [PubMed]

27. Gomis, R.R.; Alarcon, C.; He, W.; Wang, Q.; Seoane, J.; Lash, A.; Massague, J. A FoxO-Smad synexpression group in human keratinocytes. Proc. Natl. Acad. Sci. USA 2006, 103, 12747-12752. [CrossRef] [PubMed]

28. Koinuma, D.; Tsutsumi, S.; Kamimura, N.; Taniguchi, H.; Miyazawa, K.; Sunamura, M.; Imamura, T.; Miyazono, K.; Aburatani, H. Chromatin immunoprecipitation on microarray analysis of Smad2/3 binding sites reveals roles of ETS1 and TFAP2A in transforming growth factor $\beta$ signaling. Mol. Cell. Biol. 2009, 29, 172-186. [CrossRef] [PubMed]

29. Massague, J. TGF $\beta$ in Cancer. Cell 2008, 134, 215-230. [CrossRef] [PubMed]

30. Singha, P.K.; Yeh, I.T.; Venkatachalam, M.A.; Saikumar, P. Transforming growth factor- $\beta$ (TGF- $\beta$ )-inducible gene TMEPAI converts TGF- $\beta$ from a tumor suppressor to a tumor promoter in breast cancer. Cancer Res. 2010, 70, 6377-6383. [CrossRef] [PubMed]

31. Gong, C.; Qu, S.; Liu, B.; Pan, S.; Jiao, Y.; Nie, Y.; Su, F.; Liu, Q.; Song, E. MiR-106b expression determines the proliferation paradox of TGF- $\beta$ in breast cancer cells. Oncogene 2015, 34, 84-93. [CrossRef] [PubMed]

32. Johansson, J.; Berg, T.; Kurzejamska, E.; Pang, M.F.; Tabor, V.; Jansson, M.; Roswall, P.; Pietras, K.; Sund, M.; Religa, P.; et al. MiR-155-mediated loss of C/EBP $\beta$ shifts the TGF- $\beta$ response from growth inhibition to epithelial-mesenchymal transition, invasion and metastasis in breast cancer. Oncogene 2013, 32, 5614-5624. [CrossRef] [PubMed]

33. Rivlin, N.; Brosh, R.; Oren, M.; Rotter, V. Mutations in the p53 Tumor Suppressor Gene: Important Milestones at the Various Steps of Tumorigenesis. Genes Cancer 2011, 2, 466-474. [CrossRef] [PubMed]

34. Elston, R.; Inman, G.J. Crosstalk between p53 and TGF- $\beta$ Signalling. J. Signal Transduct. 2012, 2012, 294097. [CrossRef] [PubMed]

35. Dupont, S.; Zacchigna, L.; Adorno, M.; Soligo, S.; Volpin, D.; Piccolo, S.; Cordenonsi, M. Convergence of p53 and TGF- $\beta$ signaling networks. Cancer Lett. 2004, 213, 129-138. [CrossRef] [PubMed]

36. Termen, S.; Tan, E.J.; Heldin, C.H.; Moustakas, A. p53 regulates epithelial-mesenchymal transition induced by transforming growth factor $\beta$. J. Cell. Physiol. 2013, 228, 801-813. [CrossRef] [PubMed]

37. Chang, C.J.; Chao, C.H.; Xia, W.; Yang, J.Y.; Xiong, Y.; Li, C.W.; Yu, W.H.; Rehman, S.K.; Hsu, J.L.; Lee, H.H.; et al. p53 regulates epithelial-mesenchymal transition and stem cell properties through modulating miRNAs. Nat. Cell Biol. 2011, 13, 317-323. [CrossRef] [PubMed]

38. Gregory, P.A.; Bracken, C.P.; Smith, E.; Bert, A.G.; Wright, J.A.; Roslan, S.; Morris, M.; Wyatt, L.; Farshid, G.; Lim, Y.Y.; et al. An autocrine TGF- $\beta / Z E B / m i R-200$ signaling network regulates establishment and maintenance of epithelial-mesenchymal transition. Mol. Biol. Cell 2011, 22, 1686-1698. [CrossRef] [PubMed]

39. Gregory, P.A.; Bert, A.G.; Paterson, E.L.; Barry, S.C.; Tsykin, A.; Farshid, G.; Vadas, M.A.; Khew-Goodall, Y.; Goodall, G.J. The miR-200 family and miR-205 regulate epithelial to mesenchymal transition by targeting ZEB1 and SIP1. Nat. Cell Biol. 2008, 10, 593-601. [CrossRef] [PubMed]

40. Burk, U.; Schubert, J.; Wellner, U.; Schmalhofer, O.; Vincan, E.; Spaderna, S.; Brabletz, T. A reciprocal repression between ZEB1 and members of the miR-200 family promotes EMT and invasion in cancer cells. EMBO Rep. 2008, 9, 582-589. [CrossRef] [PubMed]

41. Ohainmhire, E.; Quartuccio, S.M.; Cheng, W.; Ahmed, R.A.; King, S.M.; Burdette, J.E. Mutation or loss of p53 differentially modifies TGF $\beta$ action in ovarian cancer. PLoS ONE 2014, 9, e89553.

42. Kalo, E.; Buganim, Y.; Shapira, K.E.; Besserglick, H.; Goldfinger, N.; Weisz, L.; Stambolsky, P.; Henis, Y.I.; Rotter, V. Mutant p53 attenuates the SMAD-dependent transforming growth factor $\beta 1$ (TGF- $\beta 1$ ) signaling pathway by repressing the expression of TGF- $\beta$ receptor type II. Mol. Cell. Biol. 2007, 27, 8228-8242. [CrossRef] [PubMed]

43. Her, N.G.; Jeong, S.I.; Cho, K.; Ha, T.K.; Han, J.; Ko, K.P.; Park, S.K.; Lee, J.H.; Lee, M.G.; Ryu, B.K.; et al. PPARdelta promotes oncogenic redirection of TGF- $\beta 1$ signaling through the activation of the ABCA1-Cav1 pathway. Cell Cycle 2013, 12, 1521-1535. [CrossRef] [PubMed] 
44. Leight, J.L.; Wozniak, M.A.; Chen, S.; Lynch, M.L.; Chen, C.S. Matrix rigidity regulates a switch between TGF-ß1-induced apoptosis and epithelial-mesenchymal transition. Mol. Biol. Cell 2012, 23, 781-791. [CrossRef] [PubMed]

45. Bierie, B.; Moses, H.L. Tumour microenvironment: TGF $\beta$ : The molecular Jekyll and Hyde of cancer. Nat. Rev. Cancer 2006, 6, 506-520. [CrossRef] [PubMed]

46. Wrzesinski, S.H.; Wan, Y.Y.; Flavell, R.A. Transforming growth factor- $\beta$ and the immune response: Implications for anticancer therapy. Clin. Cancer Res. 2007, 13, 5262-5270. [CrossRef] [PubMed]

47. Neuzillet, C.; Tijeras-Raballand, A.; Cohen, R.; Cros, J.; Faivre, S.; Raymond, E.; de Gramont, A. Targeting the TGF $\beta$ pathway for cancer therapy. Pharmacol. Ther. 2015, 147, 22-31. [CrossRef] [PubMed]

48. Lampropoulos, P.; Zizi-Sermpetzoglou, A.; Rizos, S.; Kostakis, A.; Nikiteas, N.; Papavassiliou, A.G. TGF- $\beta$ signalling in colon carcinogenesis. Cancer Lett. 2012, 314, 1-7. [CrossRef] [PubMed]

49. Connolly, E.C.; Freimuth, J.; Akhurst, R.J. Complexities of TGF- $\beta$ targeted cancer therapy. Int. J. Biol. Sci. 2012, 8, 964-978. [CrossRef] [PubMed]

50. Padua, D.; Massague, J. Roles of TGF $\beta$ in metastasis. Cell Res. 2009, 19, 89-102. [CrossRef] [PubMed]

51. Arteaga, C.L. Inhibition of TGF $\beta$ signaling in cancer therapy. Curr. Opin. Genet. Dev. 2006, 16, 30-37. [CrossRef] [PubMed]

52. Akhurst, R.J.; Hata, A. Targeting the TGF $\beta$ signalling pathway in disease. Nat. Rev. Drug Discov. 2012, 11, 790-811. [CrossRef] [PubMed]

53. Huang, S.; Czech, M.P. The GLUT4 glucose transporter. Cell Metab. 2007, 5, 237-252. [CrossRef] [PubMed]

54. Gordon, M.S.; Ilaria, R., Jr.; de Alwis, D.P.; Mendelson, D.S.; McKane, S.; Wagner, M.M.; Look, K.Y.; LoRusso, P.M. A phase I study of tasisulam sodium (LY573636 sodium), a novel anticancer compound, administered as a 24-h continuous infusion in patients with advanced solid tumors. Cancer Chemother. Pharmacol. 2013, 71, 21-27. [CrossRef] [PubMed]

55. Sheen, Y.Y.; Kim, M.J.; Park, S.A.; Park, S.Y.; Nam, J.S. Targeting the Transforming Growth Factor- $\beta$ Signaling in Cancer Therapy. Biomol. Ther. (Seoul) 2013, 21, 323-331. [CrossRef] [PubMed]

56. Forrester, E.; Chytil, A.; Bierie, B.; Aakre, M.; Gorska, A.E.; Sharif-Afshar, A.R.; Muller, W.J.; Moses, H.L. Effect of conditional knockout of the type II TGF- $\beta$ receptor gene in mammary epithelia on mammary gland development and polyomavirus middle $\mathrm{T}$ antigen induced tumor formation and metastasis. Cancer Res. 2005, 65, 2296-2302. [CrossRef] [PubMed]

57. Novitskiy, S.V.; Forrester, E.; Pickup, M.W.; Gorska, A.E.; Chytil, A.; Aakre, M.; Polosukhina, D.; Owens, P.; Yusupova, D.R.; Zhao, Z.; et al. Attenuated transforming growth factor $\beta$ signaling promotes metastasis in a model of HER2 mammary carcinogenesis. Breast Cancer Res. 2014, 16, 425. [CrossRef] [PubMed]

58. Muraoka-Cook, R.S.; Kurokawa, H.; Koh, Y.; Forbes, J.T.; Roebuck, L.R.; Barcellos-Hoff, M.H.; Moody, S.E.; Chodosh, L.A.; Arteaga, C.L. Conditional overexpression of active transforming growth factor $\beta 1$ in vivo accelerates metastases of transgenic mammary tumors. Cancer Res. 2004, 64, 9002-9011. [CrossRef] [PubMed]

59. Bornstein, S.; White, R.; Malkoski, S.; Oka, M.; Han, G.; Cleaver, T.; Reh, D.; Andersen, P.; Gross, N.; Olson, S.; et al. Smad4 loss in mice causes spontaneous head and neck cancer with increased genomic instability and inflammation. J. Clin. Investig. 2009, 119, 3408-3419. [CrossRef] [PubMed]

60. Lu, S.L.; Herrington, H.; Reh, D.; Weber, S.; Bornstein, S.; Wang, D.; Li, A.G.; Tang, C.F.; Siddiqui, Y.; Nord, J.; et al. Loss of transforming growth factor- $\beta$ type II receptor promotes metastatic head-and-neck squamous cell carcinoma. Genes Dev. 2006, 20, 1331-1342. [CrossRef] [PubMed]

61. Akhurst, R.J. TGF $\beta$ signaling in health and disease. Nat. Genet. 2004, 36, 790-792. [CrossRef] [PubMed]

62. Mao, J.H.; Saunier, E.F.; de Koning, J.P.; McKinnon, M.M.; Higgins, M.N.; Nicklas, K.; Yang, H.T.; Balmain, A.; Akhurst, R.J. Genetic variants of $T g f b 1$ act as context-dependent modifiers of mouse skin tumor susceptibility. Proc. Natl. Acad. Sci. USA 2006, 103, 8125-8130. [CrossRef] [PubMed]

63. Freimuth, J.; Clermont, F.F.; Huang, X.; DeSapio, A.; Tokuyasu, T.A.; Sheppard, D.; Akhurst, R.J. Epistatic interactions between $T g f b 1$ and genetic loci, $T g f b m 2$ and $T g f b m 3$, determine susceptibility to an asthmatic stimulus. Proc. Natl. Acad. Sci. USA 2012, 109, 18042-18047. [CrossRef] [PubMed]

64. Malkoski, S.P.; Haeger, S.M.; Cleaver, T.G.; Rodriguez, K.J.; Li, H.; Lu, S.L.; Feser, W.J.; Baron, A.E.; Merrick, D.; Lighthall, J.G.; et al. Loss of transforming growth factor $\beta$ type II receptor increases aggressive tumor behavior and reduces survival in lung adenocarcinoma and squamous cell carcinoma. Clin. Cancer Res. 2012, 18, 2173-2183. [CrossRef] [PubMed] 
65. McCoy, E.L.; Iwanaga, R.; Jedlicka, P.; Abbey, N.S.; Chodosh, L.A.; Heichman, K.A.; Welm, A.L.; Ford, H.L. Six1 expands the mouse mammary epithelial stem/progenitor cell pool and induces mammary tumors that undergo epithelial-mesenchymal transition. J. Clin. Investig. 2009, 119, 2663-2677. [CrossRef] [PubMed]

66. Micalizzi, D.S.; Christensen, K.L.; Jedlicka, P.; Coletta, R.D.; Baron, A.E.; Harrell, J.C.; Horwitz, K.B.; Billheimer, D.; Heichman, K.A.; Welm, A.L.; et al. The Six1 homeoprotein induces human mammary carcinoma cells to undergo epithelial-mesenchymal transition and metastasis in mice through increasing TGF- $\beta$ signaling. J. Clin. Investig. 2009, 119, 2678-2690. [CrossRef] [PubMed]

67. Micalizzi, D.S.; Wang, C.A.; Farabaugh, S.M.; Schiemann, W.P.; Ford, H.L. Homeoprotein Six1 increases TGF- $\beta$ type I receptor and converts TGF- $\beta$ signaling from suppressive to supportive for tumor growth. Cancer Res. 2010, 70, 10371-10380. [CrossRef] [PubMed]

68. Sun, S.H.; Liu, D.; Deng, Y.T.; Zhang, X.X.; Wan, D.Y.; Xi, B.X.; Huang, W.; Chen, Q.; Li, M.C.; Wang, M.W.; et al. SIX1 coordinates with TGF $\beta$ signals to induce epithelial-mesenchymal transition in cervical cancer. Oncol. Lett. 2016, 12, 1271-1278. [CrossRef] [PubMed]

69. Hocevar, B.A.; Smine, A.; Xu, X.X.; Howe, P.H. The adaptor molecule Disabled-2 links the transforming growth factor $\beta$ receptors to the Smad pathway. EMBO J. 2001, 20, 2789-2801. [CrossRef] [PubMed]

70. Prunier, C.; Howe, P.H. Disabled-2 (Dab2) is required for transforming growth factor $\beta$-induced epithelial to mesenchymal transition (EMT). J. Biol. Chem. 2005, 280, 17540-17548. [CrossRef] [PubMed]

71. Hocevar, B.A.; Prunier, C.; Howe, P.H. Disabled-2 (Dab2) mediates transforming growth factor $\beta$ (TGF $\beta$ )stimulated fibronectin synthesis through TGF $\beta$-activated kinase 1 and activation of the JNK pathway. J. Biol. Chem. 2005, 280, 25920-25927. [CrossRef] [PubMed]

72. Chaudhury, A.; Hussey, G.S.; Ray, P.S.; Jin, G.; Fox, P.L.; Howe, P.H. TGF- $\beta$-mediated phosphorylation of hnRNP E1 induces EMT via transcript-selective translational induction of Dab2 and ILEI. Nat. Cell Biol. 2010, 12, 286-293. [CrossRef] [PubMed]

73. Hannigan, A.; Smith, P.; Kalna, G.; Lo Nigro, C.; Orange, C.; O'Brien, D.I.; Shah, R.; Syed, N.; Spender, L.C.; Herrera, B.; et al. Epigenetic downregulation of human disabled homolog 2 switches TGF- $\beta$ from a tumor suppressor to a tumor promoter. J. Clin. Investig. 2010, 120, 2842-2857. [CrossRef] [PubMed]

74. Martin, J.C.; Herbert, B.S.; Hocevar, B.A. Disabled-2 downregulation promotes epithelial-to-mesenchymal transition. Br. J. Cancer 2010, 103, 1716-1723. [CrossRef] [PubMed]

75. Xu, S.; Zhu, J.; Wu, Z. Loss of Dab2 expression in breast cancer cells impairs their ability to deplete TGF- $\beta$ and induce Tregs development via TGF- $\beta$. PLoS ONE 2014, 9, e91709. [CrossRef] [PubMed]

76. Wang, W.L.; Chang, W.L.; Yang, H.B.; Wang, Y.C.; Chang, I.W.; Lee, C.T.; Chang, C.Y.; Lin, J.T.; Sheu, B.S. Low disabled-2 expression promotes tumor progression and determines poor survival and high recurrence of esophageal squamous cell carcinoma. Oncotarget 2016. [CrossRef] [PubMed]

77. Danes, C.G.; Wyszomierski, S.L.; Lu, J.; Neal, C.L.; Yang, W.; Yu, D. 14-3-3乙 down-regulates p53 in mammary epithelial cells and confers luminal filling. Cancer Res. 2008, 68, 1760-1767. [CrossRef] [PubMed]

78. Neal, C.L.; Yao, J.; Yang, W.; Zhou, X.; Nguyen, N.T.; Lu, J.; Danes, C.G.; Guo, H.; Lan, K.H.; Ensor, J.; et al. 14-3-3 $\zeta$ overexpression defines high risk for breast cancer recurrence and promotes cancer cell survival. Cancer Res. 2009, 69, 3425-3432. [CrossRef] [PubMed]

79. Lu, J.; Guo, H.; Treekitkarnmongkol, W.; Li, P.; Zhang, J.; Shi, B.; Ling, C.; Zhou, X.; Chen, T.; Chiao, P.J.; et al. 14-3-3乙 Cooperates with ErbB2 to promote ductal carcinoma in situ progression to invasive breast cancer by inducing epithelial-mesenchymal transition. Cancer Cell 2009, 16, 195-207. [CrossRef] [PubMed]

80. Xu, J.; Acharya, S.; Sahin, O.; Zhang, Q.; Saito, Y.; Yao, J.; Wang, H.; Li, P.; Zhang, L.; Lowery, F.J.; et al. 14-3-3乙 turns TGF- $\beta$ 's function from tumor suppressor to metastasis promoter in breast cancer by contextual changes of Smad partners from p53 to Gli2. Cancer Cell 2015, 27, 177-192. [CrossRef] [PubMed]

81. Kelber, J.A.; Klemke, R.L. PEAK1, a novel kinase target in the fight against cancer. Oncotarget 2010, 1, $219-223$. [CrossRef] [PubMed]

82. Wang, Y.; Kelber, J.A.; Tran Cao, H.S.; Cantin, G.T.; Lin, R.; Wang, W.; Kaushal, S.; Bristow, J.M.; Edgington, T.S.; Hoffman, R.M.; et al. Pseudopodium-enriched atypical kinase 1 regulates the cytoskeleton and cancer progression. Proc. Natl. Acad. Sci. USA 2010, 107, 10920-10925. [CrossRef] [PubMed]

83. Kelber, J.A.; Reno, T.; Kaushal, S.; Metildi, C.; Wright, T.; Stoletov, K.; Weems, J.M.; Park, F.D.; Mose, E.; Wang, Y.; et al. KRas induces a Src/PEAK1/ErbB2 kinase amplification loop that drives metastatic growth and therapy resistance in pancreatic cancer. Cancer Res. 2012, 72, 2554-2564. [CrossRef] [PubMed] 
84. Guo, Q.; Qin, W.; Li, B.; Yang, H.; Guan, J.; Liu, Z.; Li, S. Analysis of a cytoskeleton-associated kinase PEAK1 and E-cadherin in gastric cancer. Pathol. Res. Pract. 2014, 210, 793-798. [CrossRef] [PubMed]

85. Agajanian, M.; Campeau, A.; Hoover, M.; Hou, A.; Brambilla, D.; Kim, S.L.; Klemke, R.L.; Kelber, J.A. PEAK1 acts as a molecular switch to regulate context-dependent TGF $\beta$ responses in breast cancer. PLoS ONE 2015, 10, e0135748. [CrossRef] [PubMed]

86. Agajanian, M.; Runa, F.; Kelber, J.A. Identification of a PEAK1/ZEB1 signaling axis during TGF $\beta$ / fibronectininduced EMT in breast cancer. Biochem. Biophys. Res. Commun. 2015, 465, 606-612. [CrossRef] [PubMed]

87. Hollstein, M.; Sidransky, D.; Vogelstein, B.; Harris, C.C. p53 mutations in human cancers. Science 1991, 253, 49-53. [CrossRef] [PubMed]

88. Elstrom, R.L.; Bauer, D.E.; Buzzai, M.; Karnauskas, R.; Harris, M.H.; Plas, D.R.; Zhuang, H.; Cinalli, R.M.; Alavi, A.; Rudin, C.M.; et al. Akt stimulates aerobic glycolysis in cancer cells. Cancer Res. 2004, 64, 3892-3899. [CrossRef] [PubMed]

89. Zhao, Y.; Wang, L.; Huang, Q.; Jiang, Y.; Wang, J.; Zhang, L.; Tian, Y.; Yang, H. Radiosensitization of non-small cell lung cancer cells by inhibition of TGF- $\beta 1$ signaling with SB431542 is dependent on p53 Status. Oncol. Res. 2016, 24, 1-7. [CrossRef] [PubMed]

90. Alexaki, V.I.; Javelaud, D.; Van Kempen, L.C.; Mohammad, K.S.; Dennler, S.; Luciani, F.; Hoek, K.S.; Juarez, P.; Goydos, J.S.; Fournier, P.J.; et al. GLI2-mediated melanoma invasion and metastasis. J. Natl. Cancer Inst. 2010, 102, 1148-1159. [CrossRef] [PubMed]

91. Yang, L.; Xie, G.; Fan, Q.; Xie, J. Activation of the hedgehog-signaling pathway in human cancer and the clinical implications. Oncogene 2010, 29, 469-481. [CrossRef] [PubMed]

92. Dennler, S.; Andre, J.; Alexaki, I.; Li, A.; Magnaldo, T.; ten Dijke, P.; Wang, X.J.; Verrecchia, F.; Mauviel, A. Induction of sonic hedgehog mediators by transforming growth factor- $\beta$ : Smad3-dependent activation of Gli2 and Gli1 expression in vitro and in vivo. Cancer Res. 2007, 67, 6981-6986. [CrossRef] [PubMed]

93. Johnson, R.W.; Nguyen, M.P.; Padalecki, S.S.; Grubbs, B.G.; Merkel, A.R.; Oyajobi, B.O.; Matrisian, L.M.; Mundy, G.R.; Sterling, J.A. TGF- $\beta$ promotion of Gli2-induced expression of parathyroid hormone-related protein, an important osteolytic factor in bone metastasis, is independent of canonical Hedgehog signaling. Cancer Res. 2011, 71, 822-831. [CrossRef] [PubMed]

94. Baselga, J.; Rothenberg, M.L.; Tabernero, J.; Seoane, J.; Daly, T.; Cleverly, A.; Berry, B.; Rhoades, S.K.; Ray, C.A.; Fill, J.; et al. TGF- $\beta$ signalling-related markers in cancer patients with bone metastasis. Biomarkers 2008, 13, 217-236. [CrossRef] [PubMed]

95. Farrington, D.L.; Yingling, J.M.; Fill, J.A.; Yan, L.; Qian, Y.W.; Shou, J.; Wang, X.; Ehsani, M.E.; Cleverly, A.L.; Daly, T.M.; et al. Development and validation of a phosphorylated SMAD ex vivo stimulation assay. Biomarkers 2007, 12, 313-330. [CrossRef] [PubMed]

96. Dave, H.; Trivedi, S.; Shah, M.; Shukla, S. Transforming growth factor $\beta$ 2: A predictive marker for breast cancer. Indian J. Exp. Biol. 2011, 49, 879-887. [PubMed]

97. Dave, H.; Shah, M.; Trivedi, S.; Shukla, S. Prognostic utility of circulating transforming growth factor $\beta 1$ in breast cancer patients. Int. J. Biol. Markers 2012, 27, 53-59. [CrossRef] [PubMed]

98. Nishimoto, T.; Numajiri, M.; Nakazaki, H.; Okazaki, Y.; Kuwana, M. Induction of immune tolerance to platelet antigen by short-term thrombopoietin treatment in a mouse model of immune thrombocytopenia. Int. J. Hematol. 2014, 100, 341-344. [CrossRef] [PubMed]

99. Lyman, G.H.; Moses, H.L. Biomarker Tests for Molecularly Targeted Therapies-The Key to Unlocking Precision Medicine. N. Engl. J. Med. 2016, 375, 4-6. [CrossRef] [PubMed]

(C) 2016 by the authors; licensee MDPI, Basel, Switzerland. This article is an open access article distributed under the terms and conditions of the Creative Commons Attribution (CC-BY) license (http://creativecommons.org/licenses/by/4.0/). 